\title{
THE INFLUENCE OF WATER TEMPERATURE AND FLOW ON YEAR CLASS STRENGTH OF TWAITE SHAD (ALOSA FALLAX FALLAX) FROM THE RIVER SEVERN, ENGLAND.
}

\author{
M.W. APRAHAMIAN, C.D. APRAHAMIAN \\ Environment Agency, North West Region, Richard Fairclough House, Knutsford Road, \\ WARRINGTON, WA4 1HG, UK.
}

Reçu le 30 septembre 2000

Accepté le 08 mars 2001
Received 30 September, 2000

Accepted 08 March, 2001

\begin{abstract}
Year class strength (YCS) was estimated for the 25 year period between 1972 and 1996. The index (YCS) was based on the mean number of six year old female fish caught per tide (1972-1991) in a net fishery at the start of the freshwater phase of their spawning migration, or predicted from juvenile data (1992-1996). The variation in recruitment as measured by the coefficient of variation for the 20 year period (1972 to 1991) was $124.5 \%$. There was good spawning success in 1976 and 1989 and particularly poor recruitment in the periods 1977 to 1981 and 1985 to 1988 . Since 1990 recruitment has remained relatively stable.
\end{abstract}

Water temperature was positively correlated to YCS with mean July temperature explaining the greatest proportion of the variance in YCS (67\%), followed by August $(48 \%)$, June $(31 \%)$ and October $(20 \%)$; May and September temperatures did not significantly explain the variation in YCS. Flow in the months June to August were significantly inversely correlated with YCS, with the greatest proportion of the variability explained by August flows ( $41 \%)$, followed by flows in July (36\%) and June (25\%). Flows in May, September and October were not significantly correlated with YCS. Combining environmental variables in a multiple regression indicated that mean daily temperature between June and August accounted for $77.1 \%$ of the variability in year class strength. The inclusion of flow did not increase significantly the amount of variation explained. flow.

Key-words : Alosa fallax fallax, River Severn, year class strength, temperature,

\section{L'INFLUENCE DE LA TEMPÉRATURE DE L'EAU ET DU COURANT SUR L'EFFECTIF PAR CLASSE D'ÂGE DE L'ALOSE (ALOSA FALLAX FALLAX) DU FLEUVE SEVERN, ANGLETERRE.}

\section{RÉSUMÉ}

L'effectif par classe d'âge (YCS) a été estimé pour la période 1972 à 1996. L'index (YCS) était basé sur le nombre moyen des poissons femelles de 6 ans capturés par marée, ou prédit à partir des données provenant des juvéniles (1992-1996). La variation 
du recrutement, mesurée par le coefficient de variation sur une période de 20 ans (1972 à 1991) était de $124,5 \%$. Il y a eu un bon succès de ponte en 1976 et 1989, ainsi qu'un recrutement particulièrement pauvre pendant les périodes 1977-1981 et 1985-1988. Depuis 1990 le recrutement est resté relativement stable.

La température de l'eau était positivement corrélée à YCS, avec une température moyenne en juillet expliquant la plus grande proportion de la variance $(67 \%)$, suivit d'août $(48 \%)$, de juin (31\%), et d'octobre $(20 \%)$; les température de mai et septembre n'expliquent pas la variation du YCS d'une façon significative. Les courants des mois de juin à août sont inversement corrélés au YCS d'une façon significative, avec la plus grande proportion de la variabilité expliquée par le courant d'août ( $41 \%)$, suivi de juillet (36\%) et de juin (25\%). Les courants en mai, septembre et octobre ne sont pas corrélés au YCS d'une façon significative. Les variables environnementales combinées en régression multiple indiquent que la température journalière moyenne entre juin et août explique $77,1 \%$ de la variabilité de l'effectif par classe d'âge. L'inclusion du courant n'a pas augmenté d'une façon significative la variation expliquée.

Mots-clés : Alosa fallax fallax, fleuve Severn, effectif par classe d'âge (YCS), température, courant.

\section{INTRODUCTION}

Recruitment in Alosa fallax populations has been found to vary between years with good recruitment associated with warm years (HOLMES and HENDERSON, 1990). How populations are regulated, the degree to which density dependent and independent processes control a population are essential prerequisites for effective fisheries management. Such an understanding enables managers to predict trends in recruitment, abundance and understand how the population will respond to exploitation. For populations regulated mainly by density dependent processes, where fishing mortality will in part be compensated for by a reduction in natural mortality and/or an increase in growth or fecundity, the management response will be different when compared to a population that is controlled mainly by density independent factors. In the case of the latter, fishing will result in additional mortality being placed on the population.

Year class strength (YCS) of Alosa sapidissima has been shown to be mainly under the control of abiotic factors, in particular flow and temperature (MARCY, 1976 ; LEGGETT, 1977 ; CRECCO and SAVOY, 1984), and secondary related to the size of the spawning stock (CRECCO et al., 1986). Similarly HENDERSON and BROWN (1985) found that YCS for a landlocked population of Alosa pseudoharengus was determined mainly by water temperature. Though the direct mechanism has not been determined it was postulated by CRECCO and SAVOY (1987) that regulation was through advection of the larvae away from their food supply, into areas of higher predation pressure and/or into environments which the fish are not physiologically adapted.

Twaite shad enter the Severn Estuary in April at the start of the fresh water phase of their spawning migration (APRAHAMIAN, 1981). Spawning occurs between May and July with June being the main month (APRAHAMIAN, 1982). The juveniles are present in the estuary from July until they migrate seaward in the autumn (CLARIDGE and GARDNER, 1978 ; APRAHAMIAN 1988). A portion of the one-year-old fish re-enter the estuary in the spring before again migrating seaward in the autumn (APRAHAMIAN, 1988). The aim of this study was to investigate what factors were important in controlling recruitment of Alosa fallax in the River Severn. 


\section{MATERIAL AND METHODS}

\section{Catch}

The adult population of Alosa fallax fallax entering the Severn Estuary at the start of the freshwater phase of their spawning migration was sampled between 1979 and 1996. Counts of twaite shad caught were obtained from the salmon (Salmo salar L.) putcher net fishermen operating near Lydney on the Severn Estuary (National Grid Reference ST611991) (Figure 1) between April $15^{\text {th }}$ and August $15^{\text {th }}$. The putcher rank consists of 650 conical shaped traps constructed from metal bar $6 \mathrm{~mm}$ in diameter, designed to sieve fish on both the flood and ebb tides, for details see APRAHAMIAN (1981). Between 1979 and 1988 the size of the traps and their arrangement in the rank has changed, after 1988 fishing effort was constant. The changes affected the size of the opening of the traps as opposed to the spacing of the bars and thus their selectivity was considered not to be affected. The effect of the changes on fishing effort is shown in Table I. The raising factors used so that the catches taken between 1979 and 1987 were comparable with those after 1987 are presented in Table I. For the years 1982 to 1984 no estimates of fishing effort were available. Over the period 1982 to 1984 the construction material of the traps was altered from mild to stainless steel ; it was not possible to estimate the impact of this on the catch. In 1982 no sampling was possible, as the putcher rank collapsed.

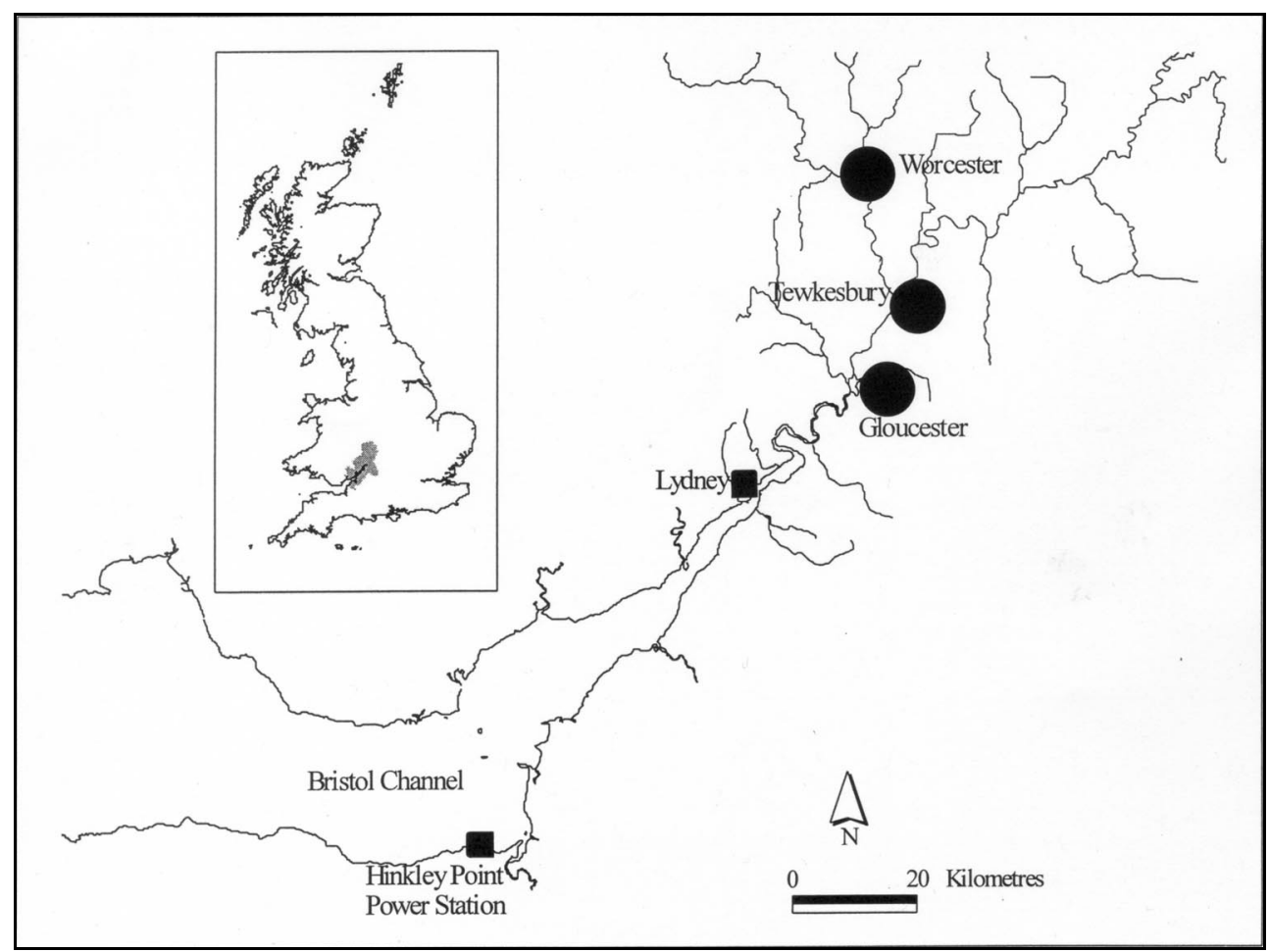

Figure 1

The lower River Severn, sampling was carried out near Lydney for adults during the freshwater phase of their spawning migration and at Hinkley Point Power Station for juvenile Alosa fallax.

\section{Figure 1}

Le bas du fleuve Severn, l'échantillonnage des adultes fut effectué près de Lydney pendant la phase de leur migration de ponte en eau douce et à la centrale électrique Hinkley Point pour les juvéniles d'Alosa fallax. 


\section{Table I}

Change in the effective fishing effort of the putcher rank over the period 1979 1996, together with the raising factors used to adjust the catch to the effort deployed between 1988 and 1996.

\section{Tableau I}

Facteurs de correction associés aux variations d'effort de pêche entre 1979 et 1996.

\begin{tabular}{|c|c|c|}
\hline Year & $\begin{array}{c}\text { Effective fishing effort } \\
\text { (arbitrary units) }\end{array}$ & Raising factor \\
\hline 1979 & 293 & 2.35 \\
\hline 1980 & 384 & 1.79 \\
\hline 1981 & 475 & 1.45 \\
\hline $1985-1986$ & 585 & 1.18 \\
\hline 1987 & 586 & 1.17 \\
\hline $1988-1996$ & 689 & 1.00 \\
\hline
\end{tabular}

Sampling was carried out between April $15^{\text {th }}$ and June $19^{\text {th }}$, the main migration period through the estuary (APRAHAMIAN, 1981). Samples of the catch or sub-samples (50 fish) of the catch if the number of fish caught exceeded 50, were taken in order to partition the run according to sex, age and spawning history. Age and spawning history was determined from scales (BAGLINIEERE et al., 2000). As the timing of the migration through the estuary differed between years (APRAHAMIAN, 1988) the migration was divided up into eight periods (week) of between 13/14 tides and one of 18 tides. The latter was the first period and took account of the number of days required to install the putcher rank. The periods were ranked according to catch per unit effort (CPUE), the top five periods were used to calculate an index of the size of the spawning stock (mean catch per tide). This was because in some years no, or relatively few, samples were taken towards the end of the run. The proportion of the available tides sampled ranged from $5 \%$ to $67 \%$ $\left(\right.$ mean $=31 \% \mathrm{yr}^{-1}$ ) and the number of fish aged ranged from 110 to 617 (mean 359 fish $\mathrm{yr}^{-1}$ ), excluding 1982 . No estimate of selectivity of the fishery was made only an index of abundance for each age class being required. The CPUE index was calculated separately for males and females as follows :

$$
\text { CPUE Index }=\sum_{i=3}^{12} \sum_{j=1}^{7} \sum_{h=1}^{5} \bar{x}_{i j k} / 5
$$

equation 1

where :

$\bar{x}=$ mean catch of shad per tide of fish age $\mathrm{i}$, spawning number $\mathrm{j}$ (spawning number 1 is a fish spawning for the first time or virgin spawner, spawning number 2 is a fish spawning for the second time it will have one spawning mark on its scale etc.) in period k. 
In the years 1979 and from 1982 to 1984 where $<10 \%$ of the total number of tides available to sample (127 tides between April $15^{\text {th }}$ and June $19^{\text {th }}$ ), the index was estimated using the change in abundance between successive age groups calculated as follows :

$$
\Delta_{\mathrm{ij}}=\log _{\mathrm{e}}\left(\mathrm{CPUE} \text { Index }(\mathrm{tt})-\log _{\mathrm{e}}(\mathrm{CPUE} \text { Index }(t+1)) \quad \text { equation } 2\right.
$$

where :

$\Delta_{\mathrm{ij}}=$ Instantaneous rate of change between successive age groups for fish of a particular age (i) and spawning number (j).

CPUE Index = the mean catch per tide for the five periods, of fish of a particular age (i) and spawning number (j).

The 1979 index was back calculated using the 1980 CPUE index and the instantaneous rate of change between the years 1980 and 1981. For the period between 1982 and 1984 the CPUE index for fish age 6 and older for sample year 1982, 7 and older for fish caught in 1983 and for fish 8 and older from 1984 were estimated from the 1981 CPUE index and the instantaneous rate of change between the years 1980 and 1981. The other age classes were back calculated from the 1985 CPUE index and the instantaneous rate of change between the years 1980 and 1981 and between 1985 and 1996. This was done to make allowance for the change in construction material and because it provided the closest approximation to the age structure recorded in 1983 and 1984. Only samples where the number of fish from a particular age group and spawning number were $\geq 5$ were used to estimate the instantaneous rate of change.

\section{Year class strength}

Year class strength (YCS) was taken as the CPUE index of female A. fallax age 6 years. The CPUE index at age 6 was used as the measure of recruitment as (1) the age at maturity was not constant between cohorts varying by up to a year and (2) at age $6>98 \%$ of the fish have matured so that a cohort can be regarded as fully recruited to the adult population (APRAHAMIAN and LESTER, 2001). For the 1974 and 1975 year classes and those between 1979 and 1991, YCS was determined directly from catch data using equation 1. For the 1973 and for the 1976 to 1978 year classes YCS was estimated from the CPUE index and the instantaneous rate of change as outlined above. The 1972 YCS was estimated from the number of seven year old fish caught in 1979, assuming that $68 \%$ of fish age 6 survive to age 7 . The survival rate was determined from the relationship between the number of fish aged six caught in year $n$ and the number of seven year old fish caught in year $\mathrm{n}+1$, for the 1973 to 1990 year classes (APRAHAMIAN and LESTER, 2001).

Quantitative monthly sampling of juvenile Alosa fallax has been carried out at Hinkley Point 'B' Nuclear Power Station (National Grid Reference ST212461) (Figure 1) since October 1980 (except during 1986) (P. HENDERSON, Pisces Conservation Ltd., IRC House, The Square, Pennington, Lymington, Hampshire, SO41 8GN, UK). Sampling dates were chosen to work tides of intermediate range in the spring-neap cycle. On each visit six consecutive one hour samples were collected in plastic baskets of $6 \mathrm{~mm}$ mesh size, positioned to collect all the debris washed from two of the four drum screens. The drums screens filter the cooling water into the power station. The debris was sorted and the number of Alosa fallax captured per hour recorded. The standard length of the fish was measured. The method is selective towards juvenile fish with the majority of $A$. fallax caught being of age 0+ (HOLMES and HENDERSON, 1990). 
For the years 1992 to 1996 YCS was estimated from the relationship between the number of juvenile twaite shad caught at Hinkley Point 'B' Nuclear Power Station between June 1 in year $n$ and May 31 in year $n+1$, and the CPUE index of six year old female shad caught in the putcher fishery in year $n+6$ (Figure 2).

YCS was transformed using natural logarithms to give the best approximation to a normal distribution.

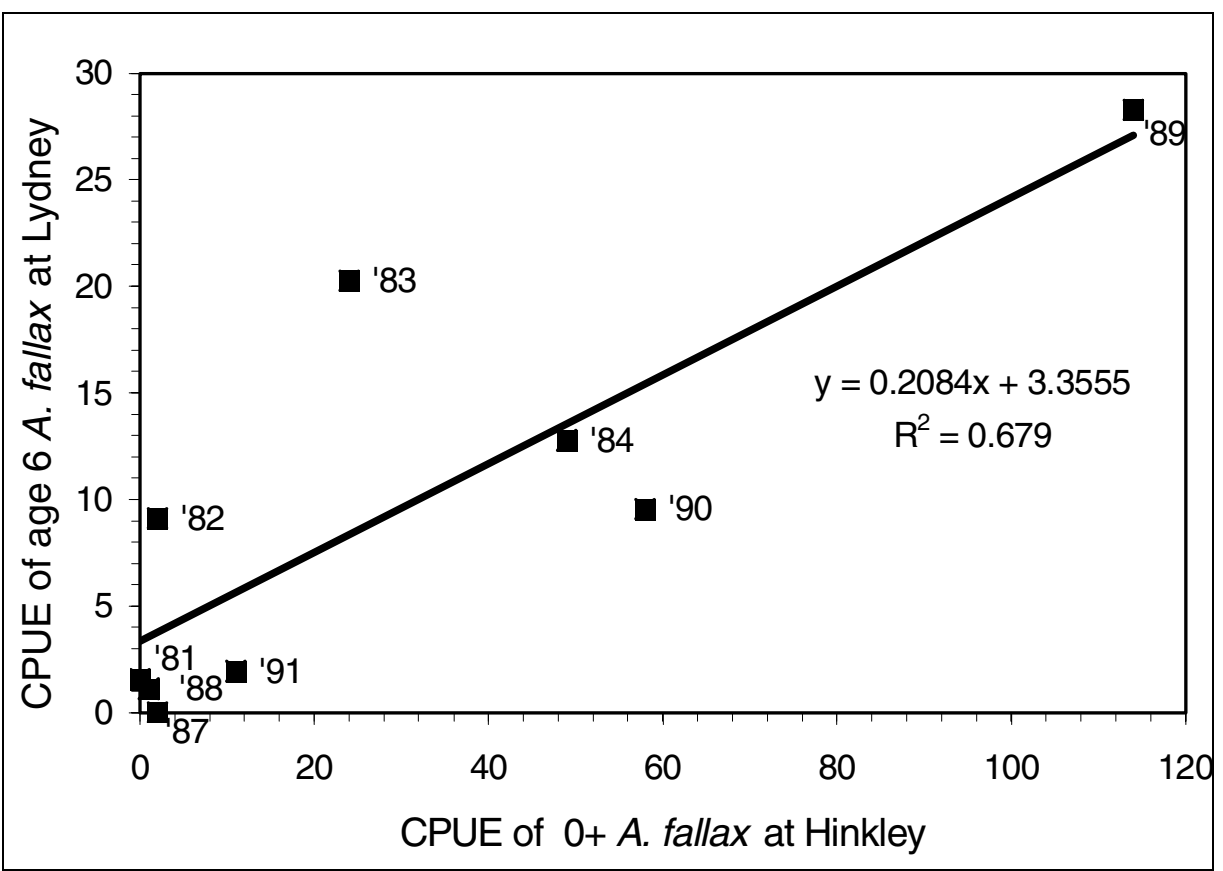

Figure 2

The relationship between the CPUE index of adult 6 year old female Alosa fallax caught at Lydney and the CPUE of juvenile (age $0+$ ) caught at Hinkley Point Power station six years previously.

\section{Figure 2}

Relation entre l'index CPUE de femelles adultes Alosa fallax de 6 ans capturées à Lydney et la CPUE de juvéniles (âge $0+$ ) capturés six ans plutôt à la centrale électrique Hinkley Point.

\section{Environmental factors}

Mean daily flow for the period 1972 to 1996 and mean daily temperature from 1989 to 1996 was obtained from Saxon's Lode on the River Severn (National Grid Reference SO863390). Daily temperature (0900 hr) in the Severn Estuary between 1972 and 1996 was obtained from Oldbury Nuclear Power Station (National Grid Reference ST603947). A significant correlation existed between the temperature recorded in the river at Saxon's Lode and that in the estuary for the months May to October 1989 to1996 $\left(r^{2}=0.69-0.95\right.$; $p \leq 0.02)$. Therefore the Oldbury data were used to represent the temperature conditions in both environments. The best approximation to a normal distribution was obtained using $\log _{e}$ flow and untransformed temperature data. 


\section{RESULTS}

The catch of twaite shad in the Severn Estuary between 1979 and 1996 reached a peak in 1982 followed by a decline to a minimum in 1985. The number caught then increased steadily attaining another peak in 1994, after which the catch declined slightly Figure 3.

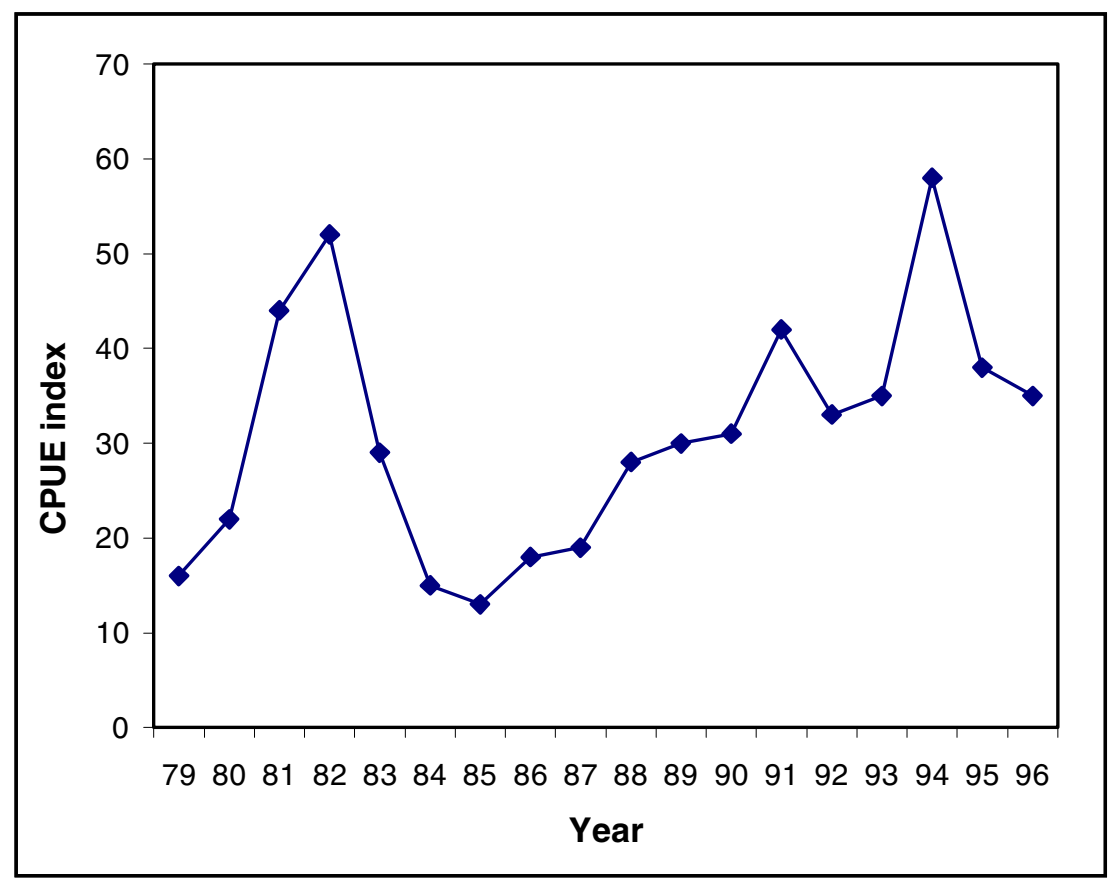

\section{Figure 3}

The CPUE index of female A. fallax caught in the Severn Estuary between 1979 and 1996.

\section{Figure 3}

L'index CPUE de femelles adultes $A$. fallax péchées dans le fleuve Severn entre 1979 et 1996.

The decline in catch between 1982 and 1985 was a consequence of poor recruitment into the adult population from the 1977 to 1981 year classes (Figure 4). The steady build up in the population from 1986 was as a result of the 1982 to 1984 year classes moving through the population. The catch in 1993 would have significantly declined had it had not been for the entrance of the 1989 year class to the spawning stock. The 1989 year class had subsequently come to dominate the population in recent years. 

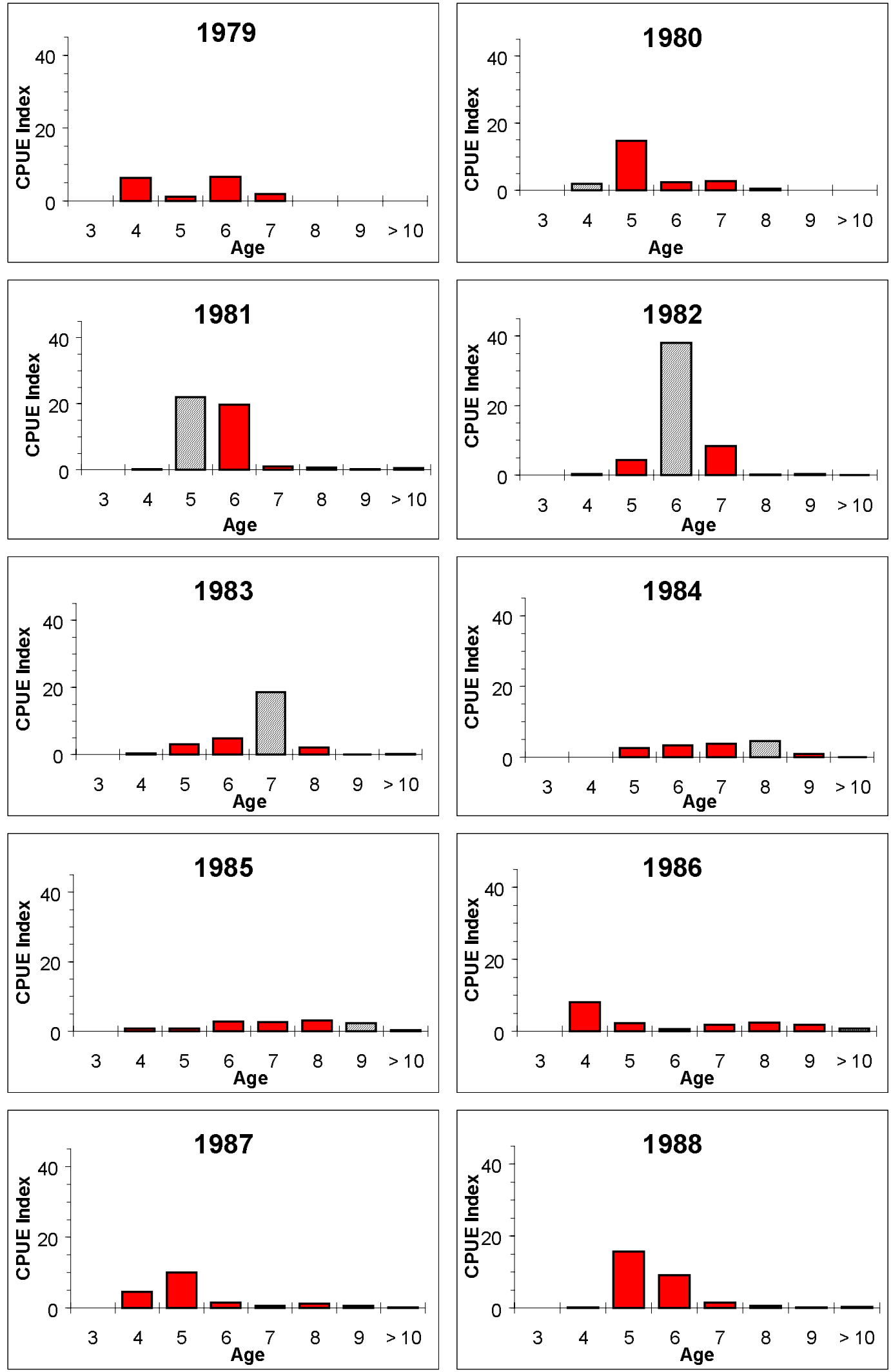

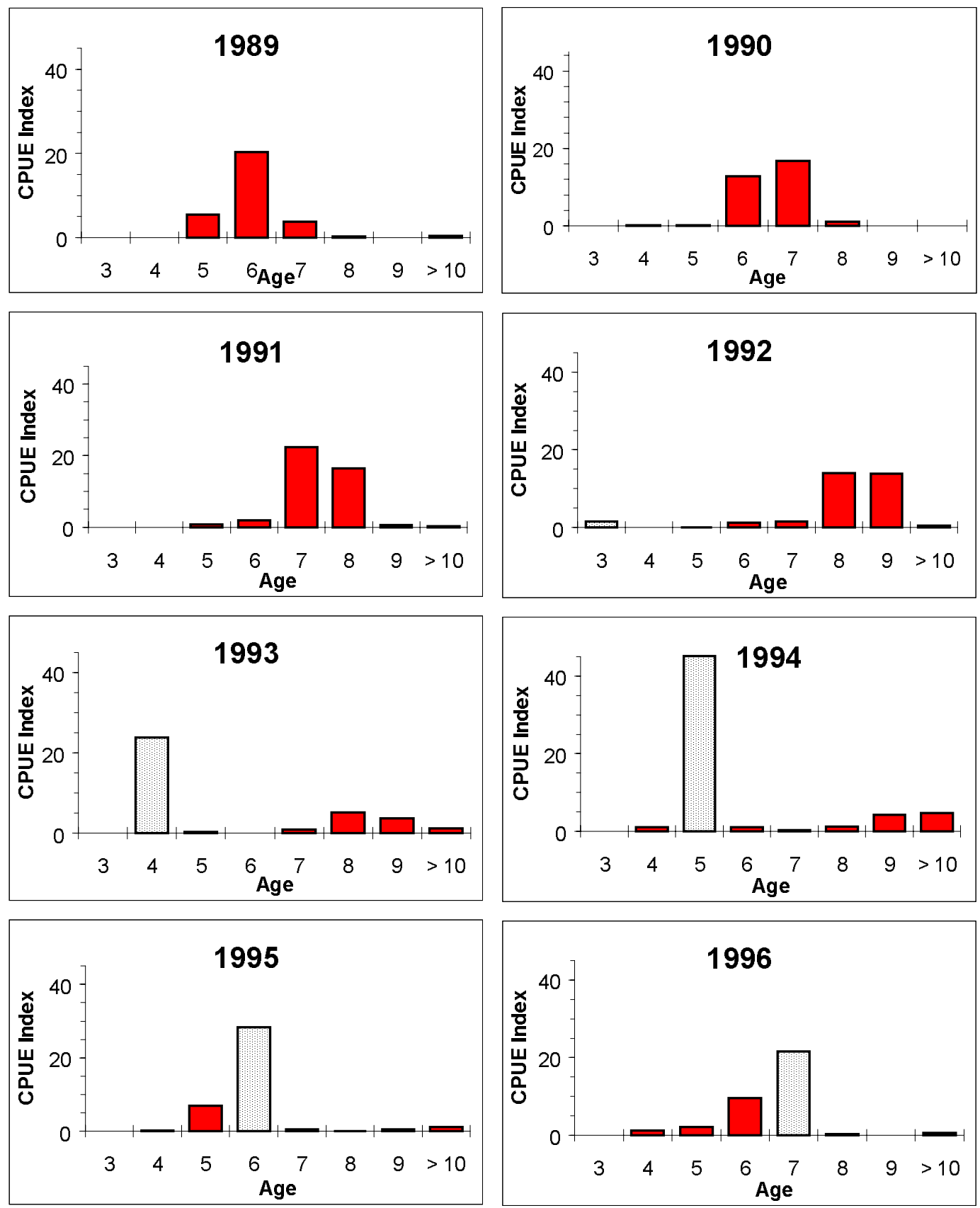

\section{Figure 4}

Age structure of the adult population between 1979 and 1996, CPUE index represents the mean catch per tide of female fish of a particular age group. The strong 1976 and 1989 year classes have been identified.

\section{Figure 4}

La structure de l'âge de la population adulte entre 1979 et 1996, CPUE index représente la capture moyenne des poissons femelles, par marée, pour un groupe d'âge donné. Les fortes classes d'âge des années 1976 et 1989 sont identifiées. 
YCS varied over the period between 1972 and 1996, with extremely good spawning success in 1976 and 1989 and particularly poor recruitment in the period from 1977 to 1981 and from 1985 to 1988 (Figure 5). Since 1990 recruitment has remained relatively stable. The variation in recruitment as measured by the coefficient of variation for the 20 year period (1972 to 1991) where recruitment was estimated from the CPUE index of 6 year old females was $124.5 \%$.

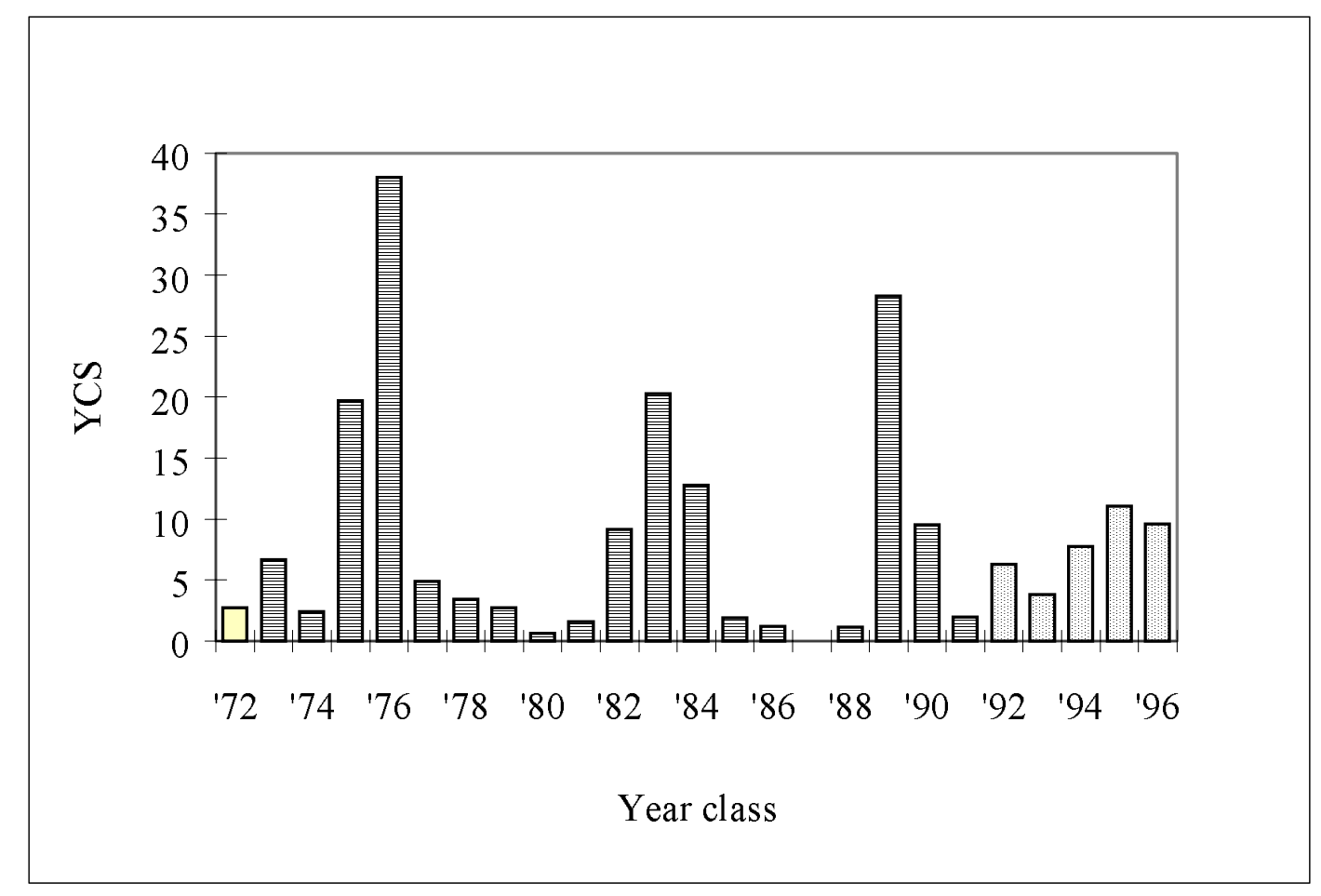

\section{Figure 5}

Index of year class strength (YCS) of Alosa fallax from the River Severn over the period 1972-1996. 1972 predicted from 7 year olds caught in 1979, 1973-1991 determined from catch of 6 year old fish and 1992-1996 predicted from the number of juveniles (age $0+$ ) caught at Hinkley Point Power Station, see text for details.

\section{Figure 5}

L'index de l'effectif par classe d'âge (YCS) de l'Alosa fallax du fleuve Severn pendant la période 1972-1996. 1972 prédit à partir de poissons de 7 ans capturés en 1979, 1973-1991 déterminé à partir de poissons de 6 ans et 1992-1996 prédit à partir du nombre de juvéniles (âge $0+$ ) attrapés à la centrale électrique Hinkley Point.

The relationship between YCS and the environmental variables was examined for the complete data set covering the 1971 to 1996 year classes and that based on catch data from the fishery i.e. the 1979 to 1991 year classes. This was carried out to determine if the effect of extrapolating and predicting data had seriously affected the relationship between YCS and the environmental variables. Table II compares the percentage of variability explained by a straight-line regression for the two time periods. Though the level 
of significance differed, reflecting in part the difference in sample size, the percentage of variability explained for the two time series was similar. This suggests that little bias was introduced as a result of extending the data series to 25 years. Further analysis was therefore carried out on the full 1972 to 1996 data set.

\section{Table II}

Comparison between the percentage of variation explained by the relationship $\log _{\mathrm{e}}$ YCS $=a+b x$ (where $x=$ temperature or $\log _{\mathrm{e}}$ Flow) for the extended data series (1972-1996 year classes) and where the index was based directly on the CPUE index of adult (age 6) $A$. fallax caught in the putcher rank (1979-1991 year classes).

\section{Tableau II}

Comparaison de coefficients de détermination des modèles prédictifs dérivés à partir de 2 échantillons : échantillon prélevé de 1979 à 1991 et échantillon extrapolé à partir de modèles prédictifs pour la période 1972 à 1996.

\begin{tabular}{|c|c|c|c|c|}
\hline \multirow{2}{*}{ Month } & \multicolumn{2}{|c|}{ Temperature } & \multicolumn{2}{c|}{ Flow } \\
\cline { 2 - 5 } & $1972-1996$ & $1979-1991$ & $1972-1996$ & $1979-1991$ \\
\hline \multirow{2}{*}{ May } & $\begin{array}{c}11.5 \\
(p>0.05)\end{array}$ & $\begin{array}{c}10.0 \\
(p>0.05)\end{array}$ & $\begin{array}{c}1.9 \\
(p>0.05)\end{array}$ & $\begin{array}{c}0.0 \\
(p>0.05)\end{array}$ \\
\hline June & $\begin{array}{c}30.9 \\
(p<0.01)\end{array}$ & $\begin{array}{c}32.0 \\
(p<0.05)\end{array}$ & $\begin{array}{c}25.1 \\
(p<0.02)\end{array}$ & $\begin{array}{c}17.4 \\
(p>0.05)\end{array}$ \\
\hline July & $\begin{array}{c}66.7 \\
(p<0.001)\end{array}$ & $\begin{array}{c}75.0 \\
(p<0.001)\end{array}$ & $\begin{array}{c}36.2 \\
(p<0.001)\end{array}$ & $\begin{array}{c}31.4 \\
(p<0.05)\end{array}$ \\
\hline September & $\begin{array}{c}47.9 \\
(p>0.05)\end{array}$ & $\begin{array}{c}46.8 \\
(p<0.01)\end{array}$ & $\begin{array}{c}41.3 \\
(p<0.001)\end{array}$ & $\begin{array}{c}44.4 \\
(p<0.02)\end{array}$ \\
\hline October & $\begin{array}{c}19.8 \\
(p<0.05)\end{array}$ & $\begin{array}{c}38.3 \\
(p<0.05)\end{array}$ & $\begin{array}{c}3.2 \\
(p>0.05)\end{array}$ & $\begin{array}{c}11.0 \\
(p>0.05)\end{array}$ \\
\hline
\end{tabular}

The relationship between $\log _{e}$ YCS, water temperature and $\log _{e}$ flow for the months May to October in their first year are shown in Figure 6 and 7. Water temperature was positively correlated to YCS with mean July temperature explaining the greatest proportion of the variance in YCS, followed by August, June and October ; May and September did not significantly explain the variation in YCS (Table II). 

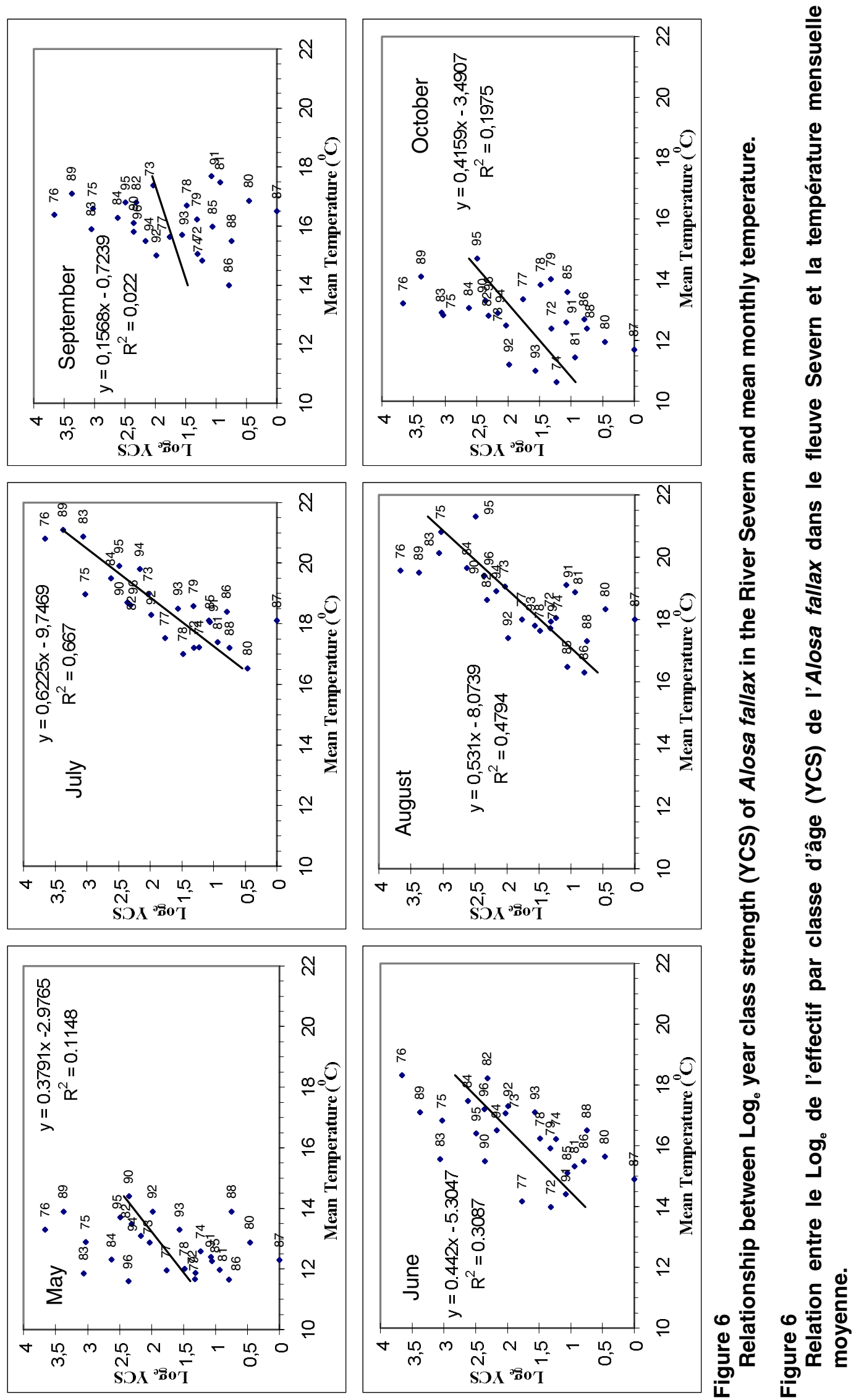

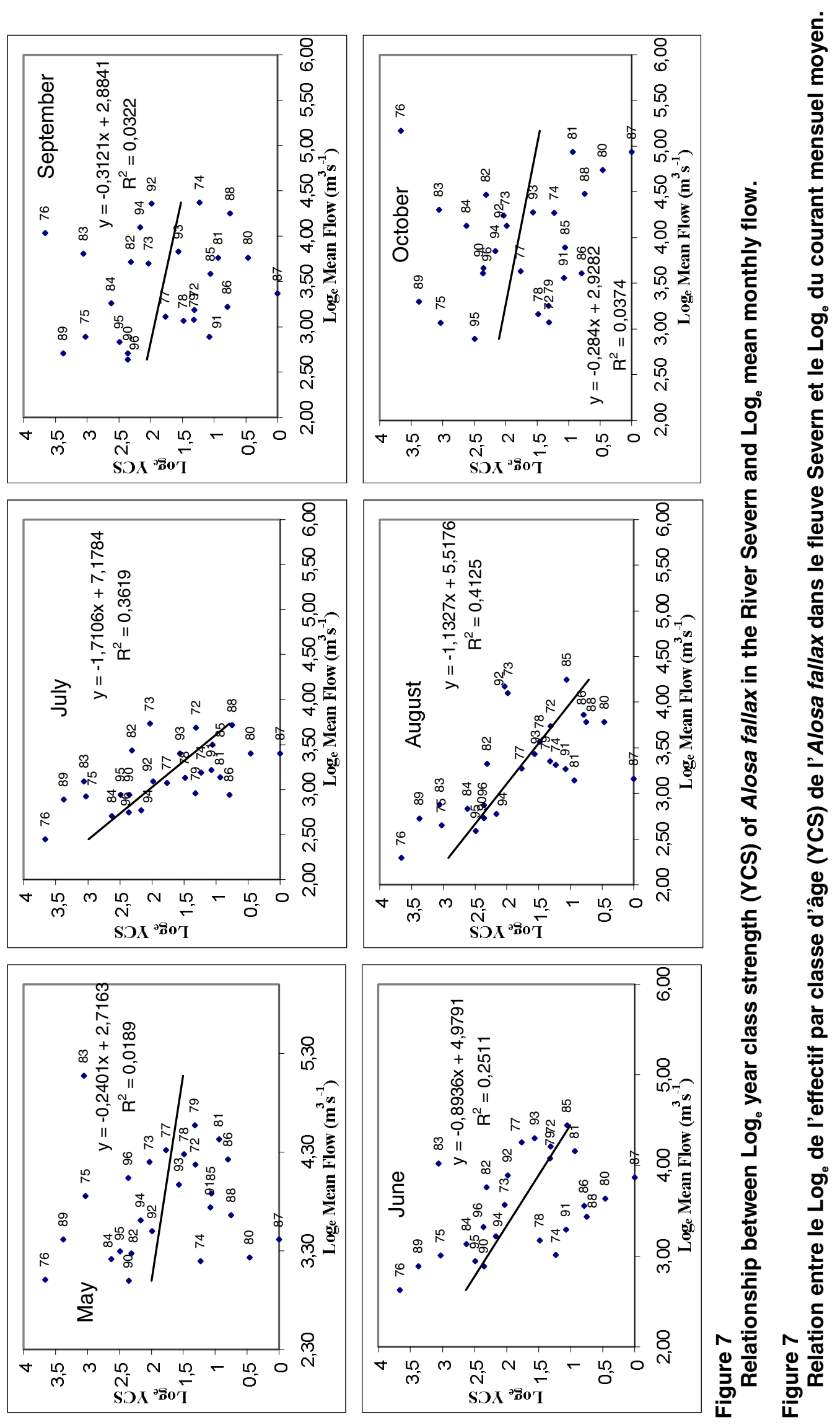
Flows in the months June to August were significantly inversely correlated with YCS, with the greatest proportion of the variability explained by August flows, followed by flows in July and June. Flows in May, September and October were not significantly correlated with YCS (Table II).

The monthly environmental variables were analysed in various combinations using multiple regression. Mean temperature in June to August explained a significant portion of the variability, the inclusion of additional variables did not increase significantly the level of variability explained. Mean temperature for the three month period accounted for $77.1 \%$ of the variability in $\log _{\mathrm{e}}$ YCS (Figure 8).

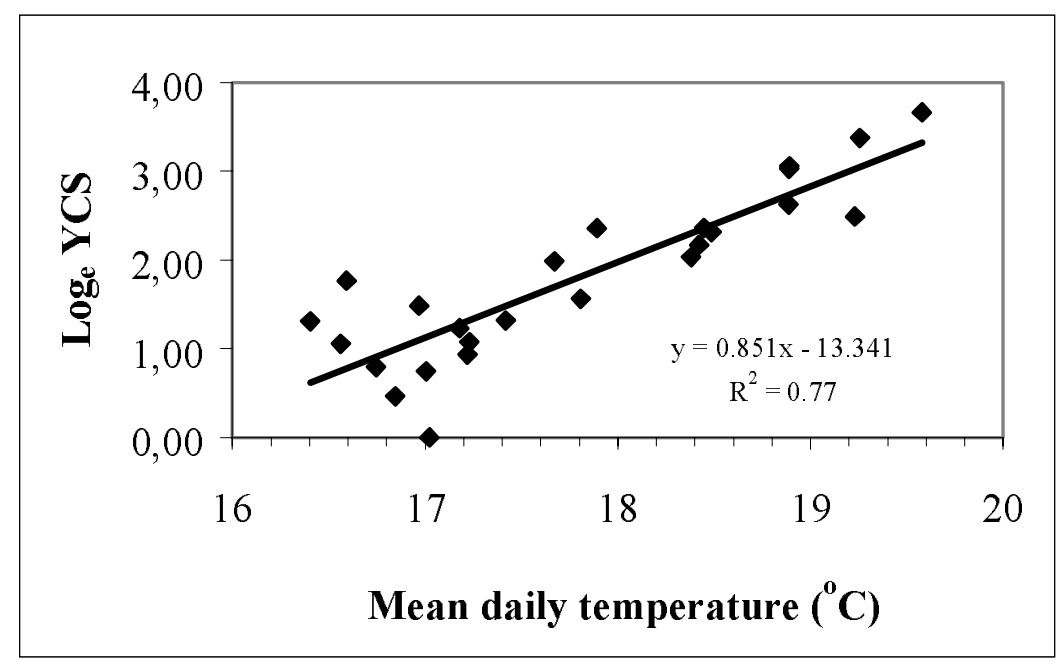

Figure 8

The relationship between $\log _{\mathrm{e}}$ year class strength (YCS) of Alosa fallax in the River Severn and the mean temperature between June and August inclusive.

\section{Figure 8}

Relation entre le Log $_{\mathrm{e}}$ de l'effectif par classe d'âge (YCS) de l'Alosa fallax dans le fleuve Severn et la température moyenne entre juin et août inclus.

\section{DISCUSSION}

The level of variation, as measured by the coefficient of variation, in recruitment found in this study of $124.5 \%$ is similar to that reported by HENDERSON and SEABY (1999) of $110.3 \%(n=18 ; 1981$ to 1998) for 0+ Alosa fallax from the Bristol Channel and by THIEL et al. (1996) of $118.1 \%$ for the Elbe, Germany ( $n=5 ; 1989$ to 1994). It also compares very closely to that estimated for Alosa alosa from the River Loire (France) of $124.4 \%$ for the 1980 to 1992 year classes (MENNESSON-BOISNEAU et al., 1999). However, the spawning in 1983 coincided with a 1:100 year flood, which opened up much of the Loire that was usually inaccessible to allis shad for reproduction. If the 1983 year class was excluded then the coefficient of variation reduced to $55.8 \%$. This level of variation in recruitment for the Severn population of Alosa fallax is likely to have lead to the adoption of iteroparity (ROFF, 1992) with fish in the Severn spawning as many as seven times (MENNESSON-BOISNEAU et al., 2000).

The extension of the data set by extrapolation and prediction did not alter the conclusion that water temperature was positively correlated and river flow negatively 
correlated with YCS. This is in agreement with the conclusions of HOLMES and HENDERSON (1990) that good recruitment is associated with warm years. The prediction of the adult CPUE index of female fish aged 6 from the CPUE of juvenile fish six years previous was very dependent on the 1989 year class, to provide greater confidence in the relationship more data where the CPUE of the juveniles is > 60 ind. $\mathrm{yr}^{-1}$ are required. $68 \%$ of the variability in the CPUE index of females age 6 was accounted for by the CPUE of juveniles six year previous. Part of the unexplained variance $(32 \%)$ may relate to the fact that not all fish experience the same level of mortality as a result of (1) spatial segregation and (2) variation in the age at maturity. It has been hypothesised that the population congregates at sea (APRAHAMIAN, 1985 ; APRAHAMIAN and LESTER, 2001) and are thus considered to be subject to the same or similar environmental pressures. However, it is realised that an unknown portion of the population re-enter the estuary the following April (APRAHAMIAN, 1988) and are thus unlikely to be subject to the same abiotic and biotic conditions as those fish which remain at sea. Part of the unexplained variance may also relate to differences in mortality pre and post maturation. APRAHAMIAN and LESTER (2001) found that some year classes notably the 1976 year class matured mainly at ages 5 and 6 and thus experienced mainly pre-maturity levels of mortality. While the 1982 year class matured at age 4 and thus by age 6 had experienced a combination of both immature and adult mortality levels. Though the instantaneous rate of mortality once fish have matured has been estimated at $0.53 \pm 0.18$ (APRAHAMIAN, 1998), no estimate of mortality pre-maturation has been determined.

The importance of environmental factors in regulating the size of anadromous Alosa populations has also been reported by CRECCO and SAVOY (1984), LEGGETT (1977) and MARCY (1976). CRECCO and SAVOY (1984) found that June temperature, river flow and precipitation explained $40.2 \%, 46.2 \%$ and $50.4 \%$ of the variability in YCS $(P<0.05)$ for $A$. sapidissima and correlation coefficients for all other months were generally $<0.3$ $(P>0.05)$. YCS was positively correlated with temperature and inversely related to flow and rainfall. MARCY (1976) reported that $46 \%$ of the total variation in the production of juvenile A.sapidissima could be explained by river discharge during June, though this was not significant at the $5 \%$ level of probability. However, a multiple regression relating juvenile abundance to both density independent and dependent factors which explained $86 \%$ of the total variation, showed river discharge to be the most important factor, followed by temperature with a smaller influence from the number of adults available to spawn. However, LEGGETT (1977) reported that of these three variables, river discharge was the least important explaining between $0.7 \%$ and $3.0 \%$ of the variation in juvenile abundance (this difference was found to be the result of miscalculation of the data by MARCY (1976) (W.C. LEGGETT, Queens University, Kingston, Ontario, K7I 3N6, Canada). SHOUBRIDGE and LEGGETT (1978) found that $58 \%$ of the variation in YCS for A. sapidissima could be predicted from water temperature during and shortly after spawning, indicating that the egg and larval stages represent the critical period. Similarly for landlocked populations of $A$. pseudoharengus, HENDERSON and BROWN (1985) found that survival of $0+$ fish was positively related to the water temperature in June $\left(r^{2}=0.28\right)$ and July $\left(r^{2}=0.18\right)$.

Temperature may be acting through a physiological response in controlling the population possibly by its effect on hatching success and/or growth rate. Spawning takes place from May through to July with peak spawning occurring in June (APRAHAMIAN, 1982). HOESTLANDT (1958) mentions for Alosa alosa that at temperatures below $16^{\circ} \mathrm{C}$ the larvae die in the eggs, while at temperatures below $18^{\circ} \mathrm{C}$ the larvae are not in good condition and have difficulty in emerging from the egg (CASSOU-LEINS and CASSOULEINS, 1981). MANN (1991) suggested that an increase in temperature may result in faster growth, so that the $0+$ fish pass more rapidly through the stage at which they are vulnerable to predation from aquatic invertebrates. Temperature may also be impacting on the population through its effect on food production. Certainly in the Connecticut River CRECCO and SAVOY (1987) found a significant positive correlation between YCS and 
zooplankton density, which may itself be under the control of temperature, and between YCS and the percentage of larval shad $(<13 \mathrm{~mm})$ with food in their guts. The similarity in the coefficient of variation between this study and that of HENDERSON and SEABY (1999) support the conclusion that the mechanism operates during the first four months before the fish migrate seaward in the autumn (CLARIDGE and GARDNER, 1978 ; APRAHAMIAN, 1988).

The negative effect of river flow on year class strength could act in a number of ways ; (1) an increase in unfavourable feeding conditions (increased turbidity), (2) the transport of the juvenile stages and their food to areas of low food density, (3) the transport of juveniles to areas where they are physiologically unsuited and (4) the transport of juveniles to areas of higher predation. Flow at the time of upstream migration to the spawning grounds in May did not appear to influence YCS. In contrast on the Loire high flows during the spring migration period was related to high levels of recruitment, fish being able to access infrequently used spawning grounds (MENNESSON-BOISNEAU et al.,1999). In the Severn the weirs at Worcester determine the limit of their distribution. The fact that flows in May do not appear important in determining YCS may be due to the fact that over the period between 1972 and 1996 flows have not been great enough to make the weirs passable.

The inclusion of environmental factors in stock recruitment models has been found to increase significantly their prediction capability. Models incorporating a combination of environmental factors (June flow, May flow, May and June rainfall) and parent stock size was found to explain between 80.5 and $88.9 \%$ of the variability in recruitment for A. sapidissima in the Connecticut River (CRECCO et al., 1986 ; CRECCO and SAVOY, 1987). Density dependent effects on recruitment have been reported for Alosa sapidissima on the Connecticut River by LEGGETT (1976), (1977) and by CRECCO et al. (1986). LEGGETT (1977) showed for $A$. sapidissima on the Connecticut River that both egg to adult survival and growth rate of juvenile (age 0+) American shad was negatively correlated with the size of the spawning stock. Similarly CRECCO et al. (1986) reported that density dependent factors accounted for $26 \%$ of the variability in year class strength of American shad from the Connecticut River. Strong density dependent regulation is also evident from the study of Alosa alosa in the Loire by MENNESSON-BOISNEAU et al. (1999). It is apparent from the data that when the dominant 1983 year class matured the abundance of the resulting progeny were at a similar level to that of the other year classes studied during the period. Landlocked populations have also shown density dependent regulation with recruitment of Alosa pseudoharengus varying inversely with the size of the spawning stock (BROWN, 1972). The lack of a stock recruitment relationship has been reported by HENDERSON and BROWN (1985) for the landlocked population of A. pseudoharengus in Lake Huron. In their study density dependent factors, without the influence of climatic factors removed, accounted for between 5 to $7 \%$ of the variation in recruitment. This is similar to that obtained by CRECCO et al. (1986) for A. sapidissima on the Connecticut River of $2 \%$.

The possibility that large scale environmental factors may act on quite disparate populations in a similar way was postulated by DRIMMELEN (1951) who observed similar patterns of recruitment in Alosa fallax suggesting that large-scale climatic factors might be responsible, particularly flow and temperature. Certainly a similar pattern of recruitment exists in the Severn and Elbe (THIEL et al., 1996) with higher recruitment in 1989 and 1990 compared with the period between 1991 and 1994 (Figure 9). The summer weather pattern in England is strongly influenced by the position of the north wall of the Gulf Stream (WILLIS et al., 1995). If large-scale global weather patterns are impacting on the population then any change in its position should manifest itself in terms of a change in recruitment, with higher recruitment the further north the north wall is positioned. Figure 10 suggests there might be. 


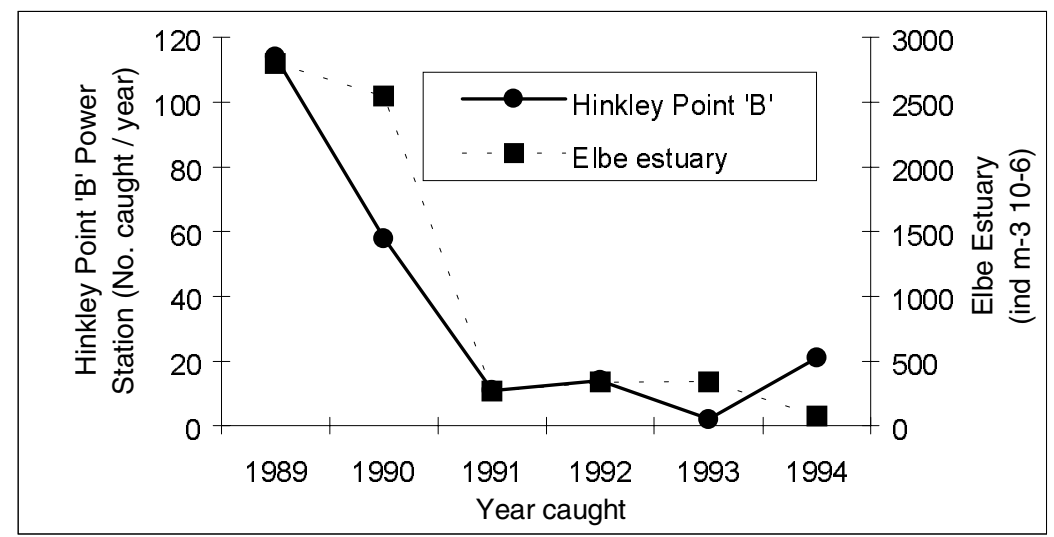

\section{Figure 9}

The number of juvenile (age $0+$ ) Alosa fallax from the Bristol Channel, at Hinkley Point 'B' Power Station and from the Elbe Estuary (THIEL et al., 1996) between 1989 and 1994.

\section{Figure 9}

Le nombre de juvéniles (âge 0+) Alosa fallax du Bristol Channel, à la centrale électrique Hinkley Point 'B' et à l'estuaire Elbe (THIEL et al., 1996) entre 1989 et 1994.

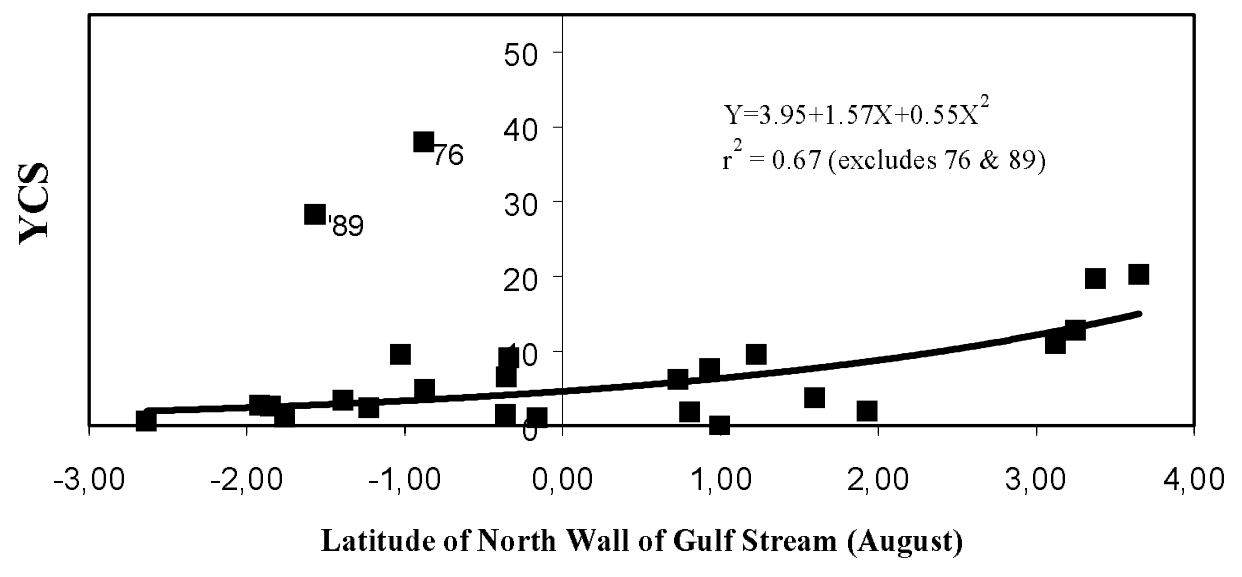

Figure 10

The relationship between year class strength of Alosa fallax from the Severn Estuary and the position of the North Wall of the Gulf Stream (First principal component of the position of the North wall of the Gulf Stream), August 1976 and 1989 year classes marked (Data from A.H. TAYLOR ; http://www.pml.ac.uk/gulfstream/inetdat.htm).

\section{Figure 10}

La relation entre l'effectif par classe d'âge de l'Alosa fallax de l'estuaire Severn et la position du mur du nord du Gulf Stream (première composante principale de la position du mur du nord du Gulf Stream), août 1976 et 1989 (données de A.H. TAYLOR ; http://www.pml.ac.uk/gulfstream/inetdat.htm). 
The indications from this study are that density independent factors are important in regulating the twaite shad population in the Severn. The implications for management are that exploitation could have a serious impact on the population in particular when there has been poor recruitment because of unfavourable environmental conditions. For example the population in the Severn was very vulnerable to over-exploitation in 1984 and 1985 when the poor recruitment year classes of 1977 to 1981 were moving through the adult population. For this reason it is important to set very conservative exploitation levels. Conservation limits (the stock size above which the population should be maintained) need to be determined for shad populations. These will need to take into account the relationship between stock and recruitment, the frequency of spawning and the environmental affects on recruitment.

\section{CONCLUSION}

The variability in recruitment (CV) of Alosa fallax in the Severn was estimated from adult catch data to be $124.5 \%$ and was similar to that reported by other studies in the Severn (HENDERSON and SEABY, 1999) and in the Elbe (THIEL et al., 1996). Year class strength of $A$. fallax was positively correlated with the mean daily temperature and negatively correlated with river flow. Multiple regression analysis indicated that water temperature was the only significant variable. Mean daily water temperature between June and August accounted for $77.1 \%$ of the variability in recruitment for the 1972 to 1996 year classes.

\section{ACKNOWLEDGEMENTS}

We are particularly grateful to P. HENDERSON for providing catch data for Hinkley Power Station. We also thank S.M. LESTER and N. MOTT for their very valuable assistance, and two anonymous referees for their comments. The project was part funded by the Environment Agency (R\&D Project W2-i640). The views expressed in this paper are those of the authors and not necessarily those of the Environment Agency.

\section{BIBLIOGRAPHY}

APRAHAMIAN M.W., 1981. Aspects of the biology of the twaite shad (Alosa fallax) in the Rivers Severn and Wye. Proceedings of the Second British Freshwater Fish Conference, 111-119.

APRAHAMIAN M.W., 1982. Aspects of the biology of the twaite shad, Alosa fallax fallax (Lacépède), in the Rivers Severn and Wye. Ph.D. Thesis, Liverpool, 381 p.

APRAHAMIAN M.W., 1985. The effect of the migration of Alosa fallax fallax (Lacépède) into fresh water, on branchial and gut parasites. Journal of Fish Biology, 27, 521532.

APRAHAMIAN M.W., 1988. The biology of the twaite shad Alosa fallax fallax (Lacépède), in the Severn Estuary. Journal of Fish Biology, 33 (Suppl. A), 141-152.

APRAHAMIAN M.W., LESTER S.M., 2001. Variation in the age at first spawning of female twaite shad (Alosa fallax fallax) from the River Severn, England. Bull. Fr. Pêche Piscic., 362/363, 941-951.

BAGLINIĖRE J.L., SABATIÉ M.R., APRAHAMIAN M.W., ALEXANDRINO P., APRAHAMIAN C.D., ASSIS C.A., CASSOU-LEINS J.J., LE CORRE M., MENNESSON-BOISNEAU C., MARTIN VANDEMBULCKE D., ROCHARD E., TEIXEIRA C., 2001. Guide pour l'interprétation des écailles et l'estimation de l'âge chez les aloses (Alosa spp.) de la façade Atlantique-est et de la Méditerranéeouest. Bull. Fr. Pêche Piscic., 357/360, 485-530. 
BROWN E.H. Jr., 1972. Population biology of alewives, Alosa pseudoharengus, in Lake Michigan, 1949-70. Journal of the Fisheries Research Board of Canada, 29, 477500.

CASSOU-LEINS F., CASSOU-LEINS J.J., 1981. Recherches sur la biologie et l'halieutique des migrateurs de la Garonne et principalement de l'alose, Alosa alosa Linné. Thèse de $3^{\mathrm{e}}$ cycle, Institut National Polytechnique de Toulouse, $393 \mathrm{p}$.

CLARIDGE P.N., GARDNER D.C., 1978. Growth and movements of the twaite shad, Alosa fallax (Lacépède), in the Severn Estuary. Journal of Fish Biology, 12, 203211.

CRECCO V.A., SAVOY T.F., 1984. Effects of fluctuations in hydrographic conditions on year-class strength of American shad (Alosa sapidissima) in the Connecticut River. Canadian Journal of Fisheries and Aquatic Science, 41, 1216-1223.

CRECCO V.A., SAVOY T.F., WHITWORTH W., 1986. Effects of density-dependent and climatic factors in American shad Alosa sapidissima, recruitment. A predictive approach. Canadian Journal of Fisheries and Aquatic Sciences, 43, 457-463.

CRECCO V.A., SAVOY T.F., 1987. Review of recruitment mechanisms of the American shad ; the critical period and match - mismatch hypotheses reexamined. American Fisheries Society Symposium, 1, 455 - 468.

DRIMMELEN D.E. VAN., 1951. Beschouwingen over de fintvangsten. Visserij-Nieuws, 2123.

HENDERSON B.A., BROWN E.H. Jr., 1985. Effects of abundance and water temperature on recruitment and growth of alewife (Alosa pseudoharengus) near South Bay, Lake Huron, 1954-82. Canadian Journal of Fisheries and Aquatic Sciences, 42, 1608-1613.

HENDERSON P.A., SEABY R.M., 1999. Population stability of the sea snail at the southern edge of its range. Journal of Fish Biology, 54, 1161-1176.

HOESTLANDT H., 1958. Reproduction de l'alose Atlantique (Alosa alosa Linné) et transfert au bassin Méditerranéen. Verhandlunden Internationale Vereinigung für Theoretische und Angewandte Limnologie, 13, 736-742.

HOLMES R.H.A., HENDERSON P.A., 1990. High fish recruitment in the Severn Estuary : the effect of a warm year? Journal of Fish Biology, 36, 961-963.

LEGGETT W.C., 1976. The American shad (Alosa sapidissima), with special reference to its migration and population dynamics in the Connecticut River. America Fisheries Society Monograph, 1, 169-225.

LEGGETT W.C., 1977. Density dependence, density independence and recruitmant in the American shad (Alosa sapidissima) population of the Conneticut River. In VAN WINKLE W. (ed.), Assessing the effects of power plant induced mortality on fish populations, 3-17, Pergamon Press, New York.

MANN R.H.K., 1991. Growth and Production. In WINFIELD I.J., NELSON J.S., (Eds.), Cyprinid fishes : Systematics, biology and exploitation, 456-482, Chapman and Hall, London.

MARCY B.C.J., 1976. Early life history studies of American shad in the lower Conneticut River and the effects of the Connecticut Yankee plant. American Fisheries Society Monograph, 1, 141-168.

MENNESSON-BOISNEAU C., APRAHAMIAN M.W., SABATIÉ M.R., CASSOU-LEINS J.J., 2000. Caractéristiques des adultes. In BAGLINIĖRE J.L., ELIE P. (Eds.). Les aloses (Alosa alosa et Alosa fallax spp.) Ecobiologie et variabilité des populations, 33-53, INRA, Paris, France, $275 \mathrm{p}$.

MENNESSON-BOISNEAU C., BOISNEAU P., POSTIC A., 1999. Abondance de la grande alose (Alosa alosa L., 1758) dans la Loire : analyse des facteurs de variabilité de 1984 à 1988 ; étude des caractéristiques biologiques des géniteurs de 1994 à 1998 ; mise au point d'un modèle de recrutement. Rapport DIREN Centre/Agence, $47 \mathrm{p}$.

ROFF D.A., 1992. The Evolution of Life Histories. Chapman and Hall, London, 535 p.

SHOUBRIDGE E.A., LEGGETT W.C., 1978. Occurrence and adaptive significance of distinct reproductive strategies in local populations of American shad. In : Genetic 
and reproductive variation in American shad, 25-73, Final Report Project AFC-10 (Connecticut), National Marine Fisheries Service US, 74 p.

THIEL R., SEPÚLVEDA A., OESMANN S., 1996. Occurrence and distribution of twaite shad (Alosa fallax Lacépède) in the lower Elbe River, Germany. In KIRCHHOFER A., HEFTI D. (Eds.), Conservation of endangered freshwater fish in Europe, 157170, Birkhäuser Verlag, Basel, Switzerland.

WILLIS A.J., DUNNETT N.P., HUNT R., GRIME J.P., 1995. Does the Gulf Stream position affect vegetation dynamics in Western Europe ? Oikos, 73, 408-410. 